\title{
Evaluation of genotoxicity and cytotoxicity of water samples from the Sinos River Basin, southern Brazil
}

\author{
Bianchi, E. ${ }^{a}$, Goldoni, A. ${ }^{a}$, Trintinaglia, L. ${ }^{b}$, Lessing, G. ${ }^{b}$, Silva, CEM. ${ }^{c}$, \\ Nascimento, CA. ${ }^{a}$, Ziulkoski, AL. ${ }^{a, d}$, Spilki, FR. ${ }^{a, e}$ and Silva, LB. ${ }^{a, f *}$ \\ aPrograma de Pós-graduação em Qualidade Ambiental, Universidade Feevale, Novo Hamburgo, RS, Brazil \\ ${ }^{\mathrm{b}}$ Curso de Biomedicina, Universidade Feevale, Novo Hamburgo, RS, Brazil \\ ${ }^{\mathrm{c}}$ Curso de Ciências Biológicas, Universidade Feevale, Novo Hamburgo, RS, Brazil \\ ${ }^{\mathrm{d}}$ Grupo de Pesquisa em Saúde Humana e Ambiente, Universidade Feevale, Novo Hamburgo, RS, Brazil \\ ${ }^{\mathrm{e}}$ Grupo de Pesquisa em Virologia Ambiental, Universidade Feevale, Novo Hamburgo, RS, Brazil \\ ${ }^{\mathrm{f}}$ Grupo de Pesquisa em Indicadores de Qualidade Ambiental, Universidade Feevale, \\ Rodovia RS-239 Km 2755, CEP 93352-000, Novo Hamburgo, RS, Brazil \\ *e-mail: lucianosilva@feevale.br
}

Received: May 24, 2013 - Accepted: August 28, 2013 - Distributed: May 31, 2015

(With 1 figure)

\begin{abstract}
Some water bodies in the Sinos River Basin (SRB) have been suffering the effects of pollution by residential, industrial and agroindustrial wastewater. The presence of cytotoxic and genotoxic compounds could compromise the water quality and the balance of these ecosystems. In this context, the research aimed to evaluate the genotoxicity and cytotoxicity of the water at four sites along the SRB (in the cities of Santo Antônio da Patrulha, Parobé, Campo Bom and Esteio), using bioassays in fish and cell culture. Samples of surface water were collected and evaluated in vitro using the Astyanax jacuhiensis fish species (micronucleus test and comet assay) and the Vero lineage of cells (comet assay and cytotoxicity tests, neutral red - NR and tetrazolium MTT). The micronucleus test in fish showed no significant differences between the sampling sites, and neither did the comet assay and the MTT and NR tests in Vero cells. The comet assay showed an increase in genetic damage in the fish exposed to water samples collected in the middle and lower sections of the basin (Parobé, Campo Bom and Esteio) when compared to the upper section of the basin (Santo Antônio da Patrulha). The results indicate contamination by genotoxic substances starting in the middle section of the SRB.
\end{abstract}

Keywords: water quality, micronucleus test, comet assay, fish bioassays, cell culture.

\section{Avaliação da genotoxicidade e da citotoxicidade de amostras de água da Bacia do Rio dos Sinos, sul do Brasil}

\begin{abstract}
Resumo
Alguns corpos d'água da Bacia Hidrográfica do Rio dos Sinos (BHRS) vêm sofrendo os efeitos da poluição por efluentes domésticos, industriais e agroindustriais. A presença de compostos citotóxicos e genotóxicos pode comprometer a qualidade da água e o equilíbrio desses ecossistemas. Neste contexto, o objetivo do trabalho foi avaliar a genotoxicidade e a citotoxicidade da água em quatro pontos ao longo da BHRS (Santo Antônio da Patrulha, Parobé, Campo Bom e Esteio), utilizando bioensaios em peixes e em cultura celular. As amostras de água de superfície foram coletadas e avaliadas in vitro utilizando a espécie de peixe Astyanax jacuhiensis (teste de micronúcleo e ensaio cometa) e a linhagem celular tipo Vero (ensaio cometa e os testes de citotoxicidade vermelho neutro - VN e tetrazólio MTT). $\mathrm{O}$ teste de micronúcleos em peixes não apresentou diferenças significativas entre os pontos de coleta, assim como o ensaio cometa e os testes VN e MTT nas células Vero. O ensaio cometa demonstrou aumento nos danos genéticos em peixes expostos às amostras de água coletadas nos trechos médio e inferior da bacia (Parobé, Campo Bom e Esteio) em relação ao trecho superior da bacia (Santo Antônio da Patrulha). Os resultados indicam contaminação por substâncias genotóxicas a partir do trecho médio da BHRS.
\end{abstract}

Palavras-chave: qualidade da água, teste de micronúcleo, ensaio cometa, bioensaios com peixes, cultura celular. 


\section{Introduction}

The Sinos River Basin (SRB) is located in the northeast of the state of Rio Grande do Sul, and is integral to the Guaíba hydrographic region. It extends over approximately $3,800 \mathrm{~km}^{2}$, encompassing 32 municipalities. The Sinos River is the main river of the basin and also one of the most important rivers in the state of Rio Grande do Sul, supplying drinking water for 1.35 million people and for an important Brazilian industrial centre (Rio Grande do Sul, 2009).

The SRB is divided into three sections: upper, middle and lower and presents a picture of water quality deterioration, especially in municipalities located in the lower section of the basin (Rio Grande do Sul, 2009). Spilki and Tundisi (2010) have reported that the Sinos River Basin is highly degraded due to a series of recurring impacts on water, soil and air quality over the years. This current situation of environmental degradation is the consequence of a process of huge economic development, arising from the footwear/leather sector and from intense urbanisation that took place with no concern for environmental conservation.

The deposition of these pollutant loads in the water leads to the formation and accumulation of complex mixtures with toxic and genotoxic potentials, which may compromise biodiversity. Additionally, processes of bioaccumulation are potentially damaging to several cell structures, such as plasma membranes, mitochondrion, lysosomes and DNA itself (Ohe et al., 2004).

Regarding the creation of applicable measures of environmental recovery and conservation that might mitigate the impacts over the basin, one priority goal suggested in order to monitor the quality of the basin is to perform research on the toxic and genotoxic effects of pollutants on plants and animals (Spilki and Tundisi, 2010).

The genotoxic analysis, when combined with a cytotoxic analysis, enables the prediction of water toxicity and genotoxicity, especially if synergism, antagonism or potentiation effects are observed in the components present in the water. These analyses have been characterised for presenting a global response, regardless of the knowledge of pollutants and their chemical properties (Žegura et al., 2009).

The use of fish as bioindicators has allowed for a reliable evaluation of the presence of pollutant sources that could potentially cause genotoxic effects, since these animals have the ability to concentrate and metabolise aquatic pollutants (Bolognesi and Hayashi, 2011).

Among alternative methodologies of environmental monitoring is the use of cell lines, which may be applied in several genotoxicity and cytotoxicity assays due to their easy manipulation and sensitivity when exposed to chemical and physical agents, in addition to presenting good reproducibility (Rogero et al., 2003; Cardozo et al., 2006; Morales, 2008; Žegura et al., 2009). Metabolically competent cell lines are among the best lines used to detect and evaluate the risks that chemical compounds can pose to human health, since they are able to reflect the metabolism of xenobiotic compounds better than other in vitro models, which demand exogenous metabolic activation (Gábelová et al., 2004).

Therefore, concerning the degradation level of the water quality in the Sinos River basin and the urban and industrial occupation of the region, the present study aimed to evaluate the citotoxicity and genotoxicity of water samples using bioassays in fish and cell culture.

\section{Material and Methods}

\subsection{Sampling sites}

Untreated water samples were collected in September 2012, from four sites located in Water Treatment Stations (WTS) along the Sinos River Basin. Each site had its location marked by the Global Positioning Satellite (GPS), as follows: Santo Antônio da Patrulha (29489.96”S/50³0'8.38”'W), a municipality located in the upper section of the basin, near the sources of Sinos River and presenting low urbanisation, with small rural areas (Vargas et al., 2001). Because of these characteristics, the site was selected as a reference in fish bioassay; Parobé $\left(29^{\circ} 36^{\prime} 8.51^{\prime \prime} \mathrm{S} / 50^{\circ} 49^{\prime} 0.56^{\prime \prime} \mathrm{W}\right)$ located in the middle section, has rice cultures and medium-sized industries in some areas; Campo Bom (2941'0.13”S/51 2'3.82'W) and Esteio (29 50'41.99'S/51 $\left.{ }^{\circ} 10^{\prime} 42.19^{\prime \prime} \mathrm{W}\right)$ are located in the lower section of the basin, where the large companies are located, such as metallurgical plants, tanneries, oil refineries and textile industries, characterising one of the highest concentrations of urban and industrial occupation in the state of Rio Grande do Sul (Rio Grande do Sul, 2009).

\subsection{Water samples}

Approximately 10 liters of water were collected in each sampling site, in accordance with to the CETESB collection protocol (São Paulo, 1988), in sterile glass bottles. After collection, the samples were stored in a thermal container, preserved with ice and transported to the Laboratory of Animal Cytogenetics, where genotoxicity tests were performed, and to the Laboratory of Molecular Microbiology, where cytotoxicity tests were performed.

\subsection{Fish bioassay}

An aquarium was filled with the water sample from each site, to which eight specimens of the Astyanax jacuhiensis (Cope, 1894) fish species were exposed during 96 hours (Udroiu, 2006), in a controlled temperature of $22^{\circ} \mathrm{C}$.

The micronucleus test consisted in collecting blood from a cut in the caudal region of each fish, dripping the blood on the surface of a glass slide. A coverslip was used to perform the smear, spreading the blood on the surface of the slide. After air-drying, the slides were fixed in absolute methanol for 10 minutes, stained using Giemsa $10 \%$ for 10 minutes, rinsed in tap water and distilled water, and finally stored in boxes, at room temperature, for subsequent analysis. All slides were analysed using an optical microscope (Nikon) with oil-immersion lens (1000x). A blind analysis was carried out for 2000 cells/animal. Other nuclear abnormalities were also analysed, such 
as blebbed and notched nuclei and binucleated cells (Carrasco et al., 1990).

The comet assay was performed according to Tice et al. (2000). This technique was performed under absence of direct light in order to avoid possible DNA damage. One microlitre of blood was collected from each fish, from the caudal region, and diluted in $90 \mu \mathrm{l}$ of fetal calf serum (FCS) $\left(\right.$ Cultilab $\left.^{\circledR}\right)$. An aliquot of this mixture (1:10) was obtained; $5 \mu$ l of this suspension were pipetted and gently mixed with $95 \mu$ l of low melting agarose $0.7 \%\left(37^{\circ} \mathrm{C}\right)$. This mixture was then applied on the slides previously coated with normal melting point agarose and a coverslip was then placed on the slide. The slides were then stored for seven minutes in a refrigerator, until the agarose layer solidified. After this period, the coverslips were gently removed and the slides were immersed in a lysis solution $(2.5 \mathrm{M} \mathrm{NaCl}, 100 \mathrm{mM}$ EDTA, $10 \mathrm{mM}$ Tris, $\mathrm{pH} 10.2,1 \%$ Triton $\mathrm{X}-100$ and $10 \%$ DMSO) for a minimum period of 24 hours, at $4{ }^{\circ} \mathrm{C}$. After removal from the lysis solution, the slides were placed in a horizontal electrophoresis box filled with fresh electrophoresis buffer $(300 \mathrm{mM} \mathrm{NaOH}, 1 \mathrm{mM}$ EDTA, $\mathrm{pH}>13)$, at $4{ }^{\circ} \mathrm{C}$. The liquid covered the slides, which were then left in the solution for 20 minutes before the power was turned on. Electrophoresis was performed at $35 \mathrm{~V}$ and $300 \mathrm{~mA}$ $(\sim 0.95 \mathrm{~V} / \mathrm{cm})$ for 25 minutes. At the end, a neutralising buffer (0.4 M Tris, $\mathrm{pH} 7.5$ ) was added to the slides. Slides were then rinsed with distilled water and left to air dry at room temperature for at least two hours. The following steps included the slides fixation and staining with silver stain according to Nadin et al. (2001).

The microscopic analysis was performed on an optical microscope (Nikon) at 400x magnification, and 100 cells were evaluated for each slide. All slides were coded and scored by a single observer. Cells were scored visually according to tail length into five categories, from undamaged (Type 0) to completely damaged (Type IV) (Anderson et al., 1994). Based on the arbitrary values assigned to the different categories (from Type $0=0$ to Type IV =4), a genetic damage index was calculated for each fish (Pitarque et al., 1999). Therefore, the total score per individual ranged from 0 (all undamaged) to 400 (all presenting maximum damage). The damage frequency (DF) was calculated as the mean percentage of cells with medium, high and complete damage (categories II, III and IV) (Palus et al., 1999).

\subsection{Bioassays in cell culture}

Initially, all untreated water samples were filtered using microfilters with a $0.22 \mu \mathrm{m}$ pore size. The culture medium was then prepared with the water samples from each site. The water was used as the diluting solution for the Dubelcco's Modified Eagle's Medium (DMEM, Sigma ${ }^{\circledR}$ ) substrate. Then, DMEM, sodium bicarbonate and Hepes buffer $\left(\right.$ Sigma $\left.^{\circledR}\right)$ were dissolved in $27 \mathrm{~mL}$ of water sample. After that, the $\mathrm{pH}$ was adjusted to 7.4 and $3 \mathrm{~mL}$ of fetal calf serum (FCS) were added. The final volume was completed with $30 \mathrm{~mL}$ of medium with $10 \%$ of FCS. The samples were filtered again in a microfilter with a $0.22 \mu \mathrm{m}$ pore size under sterile conditions and $10.000 \mathrm{U} / \mathrm{mL}$ of penicillin with $10 \mathrm{mg} / \mathrm{mL}$ of streptomycin $\left(\right.$ Sigma $^{\circledR}$ ) were added. At the end of the process, a medium culture was obtained with $100 \%$ of the water sample from each sampling site.

The Vero continuous cell line was selected; this cell line is derived from epithelial cells from the kidney of the African green monkey. The cells were stored in $25 \mathrm{~cm}^{2}$ polystyrene bottles in DMEM, supplemented with $10 \%$ FCS and antibiotics, in a humid atmosphere with a $\mathrm{CO}_{2}$ level of $5 \%$, at $37^{\circ} \mathrm{C}$.

In order to perform the cytotoxicity assays, $1.5 \times 10^{4}$ cells/well were seeded in a 96 well polystyrene microplate, according to the cell proliferation rate. After culture cells were semiconfluent, they were exposed for 24 hours to a prepared medium with each water sample. For the control cells, only standard DMEM was used. All assays were repeated in quadruplicates. Cell cultures were maintained under standard methodology.

\subsubsection{Methyl thiazolyl tetrazolium (MTT) test}

To verify mitochondrial functionality, the MTT test (3-[4,5-dimethylthiazol-2-yl]-2,5-diphenyltetrazolium bromide), was conducted, as described by Mosmann (1983). After 24 hours of exposure, $20 \mu \mathrm{L}$ of diluted MTT solution were added, and the plates were incubated for 2 hours. After incubation, the medium was removed by inversion and $200 \mu \mathrm{L}$ of DMSO were added to each well for solubilisation. All the samples were then transferred to a 96 well plate for the reading of absorbance in a microplate spectrophotometer at $540 \mathrm{~nm}$.

\subsubsection{Neutral red (NR) test}

In order to verify the lysosomal viability after the period of 24 hours, a technique known as cytotoxicity assay for the neutral red retention was performed, according to Borenfreund and Puerner (1985) and Rogero et al. (2003). The cell culture medium with water sample was then discarded and DMEM (without serum) containing $50 \mu \mathrm{g}$ of neutral $\mathrm{red} / \mathrm{mL}$ was added. After three hours of incubation at $37^{\circ} \mathrm{C}$, the medium was removed and the cells were washed twice, first with phosphate buffered saline (PBS) and then with calcium chloride with formaldehyde. After discarding the solutions, $0.2 \mathrm{~mL}$ of $1 \%$ acetic acid in $50 \%$ ethanol was added to each well and maintained in agitation for 10 minutes. The absorbance was read at $540 \mathrm{~nm}$ in a microplate spectrophotometer (TR-Reader, Thermoplate ${ }^{\circledR}$ ).

\subsubsection{Comet assay in cell culture}

For the comet assay, $10^{4}$ cells/well were seeded in 24 well polystyrene plates with DMEM, and supplemented with FBS 10\%, 24 hours before they were exposed to the treatments. The water samples from each site were used to prepare the media, then supplemented with $10 \% \mathrm{FBS}$, $\mathrm{pH} 7.4$, and subsequently filtered through microfilters with $0.22 \mu \mathrm{m}$ pores. Two periods of exposure were used: one short ( 3 hours) and one long-term ( 24 hours), each followed by four replicates. 
At the end of the treatment period of 3 and 24 hours, the cultures were washed with PBS and subsequently received trypsin for cell resuspension. The cells were then transferred to Falcon tubes and centrifuged at $1200 \mathrm{rpm}$ for 10 minutes. The cell pellet was then resuspended in $50 \mu \mathrm{l}$ of PBS, and $10 \mu \mathrm{l}$ of this suspension were mixed thoroughly with $90 \mu \mathrm{l}$ low melting point agarose $0.7 \%\left(37^{\circ} \mathrm{C}\right)$. From this stage on, the conditions were the same as described above for the comet assay in the blood cells of fish.

\subsection{Statistical analysis}

Data were expressed as mean \pm standard deviation. All analyses were carried out using the Statistical Package for the Social Sciences (SPSS) 15.0 for Windows, considering a significance level of $\mathrm{p} \leq 0.05$. The micronucleus and other nuclear abnormalities results did not presented a normal distribution. Therefore, the data on micronucleus and other nuclear abnormalities were compared using the Kruskal-Wallis test. One-way analysis of variance (ANOVA) was used to comet assay and citotoxicity results. The Tukey test was applied for post-hoc comparison. A cytotoxic response was considered when the viability values observed were below $70 \%$, when compared to the control (Boeira et al., 2001; Cardozo et al., 2006; Žegura et al., 2009).

\section{Results}

Results of the micronucleus test in the Astyanax jacuhiensis fish are presented in Table 1. Micronuclei and other nuclear abnormalities were observed in the blood

Table 1. Means and standard deviations of the frequencies of micronuclei (MN) and nuclear abnormalities (NA) observed in 1,000 erythrocytes of the Astyanax jacuhiensis fish species exposed to water samples from four sites in the Sinos River Basin.

\begin{tabular}{cccc}
\hline Sampling site & $\mathbf{n}$ & MN & NA \\
\hline Santo Antônio da & 6 & $0.0 \pm 0.0$ & $2.6 \pm 1.5$ \\
Patrulha & & & \\
Parobé & 6 & $0.0 \pm 0.2$ & $1.8 \pm 1.4$ \\
Campo Bom & 7 & $0.0 \pm 0.0$ & $2.4 \pm 2.9$ \\
Esteio & 7 & $0.1 \pm 0.4$ & $2.4 \pm 1.5$ \\
p & & 0.5 & 0.9 \\
\hline
\end{tabular}

cells of some animals. However, these types of alterations were rare and no significant differences were observed among the different sampling sites.

The frequency of damage and the indices of genetic damage estimated by the comet assay in blood cells of the fish are shown in Table 2. The results show that there were significant differences for the two parameters under study, with the fish exposed to the sample from Santo Antônio da Patrulha (reference location) presenting significantly lower values than those observed for the other three sampling sites.

The results obtained by the neutral red (NR) and tetrazolium MTT tests are presented in Figure 1. In the tetrazolium MTT test, there was no significant loss of mitochondrial function in Vero cells cultured with water samples from the four sites of the Sinos River Basin, when compared to the control group. Likewise, when using the NR test to assess cytotoxicity by lysosomal viability, no cytotoxic effect was detected in the Vero cells.

The results of the comet assay in Vero cells after $3 \mathrm{~h}$ and $24 \mathrm{~h}$ exposure are shown in Table 3 . There were no significant differences between the sampling sites for the two exposure times. Likewise, the genetic damage observed in both exposure times showed no difference, when compared between the same sampling site.

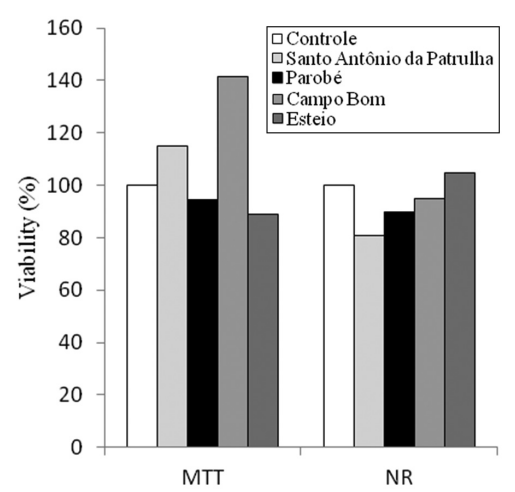

Figure 1. Viability (\%) in relation to the control group obtained by the neutral red (NR) and tetrazolium MTT tests in Vero cells, after 24 hours of exposure to the water samples from four sites in the Sinos River Basin.

Table 2. Evaluation of genotoxicity in the water from four sites in the Sinos River Basin based on the comet assay in erythrocytes of the Astyanax jacuhiensis fish species.

\begin{tabular}{cccc}
\hline Sampling site & $\mathbf{n}$ & $\begin{array}{c}\text { Damage frequency } \\
\text { (II+III+IV) }\end{array}$ & Damage index \\
\hline Santo Antônio da Patrulha & 6 & $33.3 \pm 20.4^{\mathrm{a}}$ & $112.7 \pm 68.1^{\mathrm{a}}$ \\
Parobé & 6 & $73.8 \pm 16.2^{\mathrm{b}}$ & $264.7 \pm 65.0^{\mathrm{b}}$ \\
Campo Bom & 7 & $68.0 \pm 16.2^{\mathrm{b}}$ & $224.3 \pm 44.8^{\mathrm{b}}$ \\
Esteio & 7 & $71.0 \pm 16.2^{\mathrm{b}}$ & $242.0 \pm 51.9^{\mathrm{b}}$ \\
$\mathrm{p}$ & & 0.001 & 0.001 \\
\hline
\end{tabular}

a,b Values marked with different letters in the same column have significant difference. 
Table 3. Evaluation of genotoxicity of the water from four sites in the Sinos River Basin, using the comet assay in Vero cells, after 3 and 24 hours of exposure.

\begin{tabular}{ccccc}
\hline \multirow{2}{*}{ Sampling site } & \multicolumn{2}{c}{ Damage Index } & \multicolumn{2}{c}{ Damage Frequency } \\
\cline { 2 - 5 } & 3 hours & 24 hours & 3 hours & $\mathbf{2 4}$ hours \\
\hline Santo Antônio da Patrulha & $121.5 \pm 3.5$ & $186.8 \pm 104.0$ & $24.5 \pm 3.5$ & $51.0 \pm 29.6$ \\
Parobé & $184.0 \pm 99.6$ & $190.8 \pm 64.8$ & $41.3 \pm 29.0$ & $51.0 \pm 17.3$ \\
Campo Bom & $208.7 \pm 78.6$ & $188.0 \pm 45.0$ & $48.7 \pm 26.3$ & $55.0 \pm 10.0$ \\
Esteio & $145.5 \pm 28.4$ & $173.3 \pm 47.6$ & $33.0 \pm 6.4$ & $50.3 \pm 10.6$ \\
p & 0.46 & 0.97 & 0.57 & 0.99 \\
\hline
\end{tabular}

\section{Discussion}

The middle and lower sections of the Sinos River Basin present a high concentration of urban occupation and one of the largest industrial centres in Brazil. Consequently, the water quality in this area of the basin is influenced by the direct discharge of different types of toxic substances from metallurgical, petrochemical, agricultural and livestock activities, tanneries and residences, which have the potential to cause effects on genetic and cellular levels (Vargas et al., 2001; Ohe et al., 2004; Scalon et al., 2010; Nunes et al., 2011).

Detecting and quantifying the presence of a substance by traditional analyses cannot establish its true effects on the ecosystem. Therefore, bioassays must be used in the triage of environmental samples to evaluate the toxicity of contaminated rivers, as a diagnosis and monitoring tool (Goulart and Callisto, 2003).

In this study, the micronucleus test in fish and the comet assay in fish and cell culture were used to evaluate the genotoxic potential of water from four sampling sites in the SRB. The comet assay in fish showed higher sensitivity to detect an increase in genotoxicity of the water collected in the middle and lower sections (Parobé, Campo Bom and Esteio), when compared to the sampling site located in the upper section of the basin (Santo Antônio da Patrulha). The results suggest that the Sinos River is contaminated by substances that can induce genetic damage, which could have significant consequences for short- and long-term survival of wild species (Jha, 2008).

The results of this study are consistent with what has been observed by Scalon et al. (2010) for the middle section of Sinos River, but are not consistent with findings about the upper section. Scalon et al. (2010) have assessed the genotoxicity of the water collected from three points in the Sinos River during four seasons, using the comet assay in the fish Hyphessobrycon luetkenii, having found that the frequency of cells with DNA damage was higher during spring at the sites located in the upper and middle sections. Differences between sampling sites or periods in a river could be related to differences in the sources of contamination (types of pollutants), the volume of water (alteration in the concentration of genotoxic agents) and/or the cumulative effect of different sources (Matsumoto et al., 2006).

The comet assay is known to be more sensitive in the detection of genotoxicity than the micronucleus test
(Mitchelmore and Chipman, 1998). This assay detects repairable DNA damage, such as single and double breaks in DNA strand, repair events by incomplete excisions, alkali labile sites and cross-links between DNA molecules, while the micronucleus test detects not repairable chromosome damage, such as clastogenic and aneugenic lesions (Tice et al., 2000; Bolognesi et al., 2004; Udroiu, 2006). The results of micronuclei and nuclear abnormalities suggest that the water samples of Sino River Basin do not induce chromosome breakage or loss in fish. In the lower course the demographic density is high and one of the main environmental problems is the discharge of untreated domestic sewage in tributaries and in the main river (Blume et al., 2010). The results of the present study are in agreement with findings reported by Grisolia et al. (2005) and Grisolia and Starling (2001), who also did not observe significant increase in DNA damage in fish captured in areas under influence of sewage treatment plant discharges, and in fish exposed to the final effluent of a municipal wastewater treatment plant, respectively.

The lysosomal viability (VN) and mitochondrial viability (MTT) tests are widely applied in in vitro toxicology for the assessment of cytotoxicity (Fotakis and Timbrell, 2006). The VN and MTT tests have been successfully used to detect cytotoxicity in surface water and drinking water samples (Žegura et al., 2009; Marabini et al. 2007). The results obtained with the 24-hour exposure of Vero cells to water samples from the four sampling sites do not show the presence of cytotoxic substances. In contrast, another study conducted in the SRB with the V79 cell line has found that three sites (in the cities of Canoas, São Leopoldo and Novo Hamburgo) presented cytotoxic activity during the period of June, 2006 (Nunes et al., 2011).

Water from rivers may contain mixtures of pollutants from various sources and the toxic action of each sample can vary according to the sensitivity of the assay performed (Vargas et al., 2001; Žegura et al., 2009; Rocha et al., 2010; Nunes et al., 2011). The different responses among in vitro tests could be related to the variation of experimental conditions (such as organism and cell line, dosage and time of exposure) (Maffei et al., 2009). Therefore, the use of different bioassays enables the detection of a wider spectrum of substances that could have negative effects on the biota. The use of these bioassays and the constant monitoring of the main water bodies in the Sinos River Basin should be encouraged. 


\section{Acknowledgements}

This work was partially supported by research grants from Fundação de Amparo à Pesquisa do Estado do Rio Grande do Sul (FAPERGS/PRONEX - number 10/0040-2) and Conselho Nacional de Desenvolvimento Científico e Tecnológico (CNPq, number 477784/2011-9). FRS is a CNPq researcher and EB received a student fellowship from the Coordenação de Aperfeiçoamento de Pessoal de Nível Superior (CAPES/PROSUP).

\section{References}

ANDERSON, D., YU, TW., PHILLIPS, BJ. and SCHMEZER, P., 1994. The effect of various antioxidants and other modifying agents on oxygen-radical-generated DNA damage in human lymphocytes in the COMET assay. Mutation Research, vol. 307, no. 1, p. 261-271. http://dx.doi.org/10.1016/0027-5107(94)90300-X. PMid:7513806.

BLUME, KK., MACEDO, JC., MENEGUZZI, A., SILVA, LB., QUEVEDO, DM. and RODRIGUES, MAS., 2010. Water quality assessment of the Sinos River, Southern Brazil. Brazilian Journal of Biology $=$ Revista Brasileira de Biologia, vol. 70, no. 4, supplement, p. 1185-1193.

BOEIRA, JM., SILVA, J., ERDTMANN, B. and HENRIQUES, JAP., 2001. Genotoxic effects of the alkaloids harman and harmine assessed by comet assay and chromosome aberration test in mammalian cells in vitro. Pharmacology \& Toxicology, vol. 89, no. 6, p. 287-294. http://dx.doi.org/10.1034/j.1600-0773.2001. d01-162.x. PMid:11903953.

BOLOGNESI, C. and HAYASHI, M., 2011. Micronucleus assay in aquatic animals. Mutagenesis, vol. 26, no. 1, p. 205-213. http:// dx.doi.org/10.1093/mutage/geq073. PMid:21164204.

BOLOGNESI, C., BUSCHINI, A., BRANCHI, E., CARBONI, P., FURLINI, M., MARTINO, A., MONTEVERDE, M., POLI, P. and ROSSI, C., 2004. Comet and micronucleus assays in zebra mussel cells for genotoxicity assessment of surface drinking water treated with three different disinfectants. The Science of the Total Environment, vol. 333, no. 1-3, p. 127-136. http://dx.doi. org/10.1016/j.scitotenv.2004.05.018. PMid:15364524.

BORENFREUND, E. and PUERNER, JA., 1985. Toxicity determined in vitro by morphological alterations and neutral red absorption. Toxicology Letters, vol. 24, no. 2-3, p. 119-124. http://dx.doi.org/10.1016/0378-4274(85)90046-3. PMid:3983963.

CARDOZO, TR., ROSA, DP., FEIDEN, IR., ROCHA, JA., OLIVEIRA, NC., PEREIRA, TS., PASTORIZA, TF., MARQUES, DM., LEMOS, CT., TERRA, NR. and VARGAS, VM., 2006. Genotoxicity and toxicity assessment in urban hydrographic basins. Mutation Research, vol. 603, no. 1, p. 83-96. http://dx.doi. org/10.1016/j.mrgentox.2005.11.011. PMid:16413222.

CARRASCO, KR., TILBURY, KL. and MYERS, MS., 1990. Assessment of the piscine micronucleus test as an in situ biological indicator of chemical contaminant effects. Canadian Journal of Fisheries and Aquatic Sciences, vol. 47, no. 11, p. 2123-2136. http://dx.doi.org/10.1139/f90-237.

FOTAKIS, G. and TIMBRELL, JA., 2006. In vitro cytotoxicity assays: comparison of LDH, neutral red, MTT and protein assay in hepatoma cell lines following exposure to cadmium chloride. Toxicology Letters, vol. 160, no. 2, p. 171-177. http://dx.doi. org/10.1016/j.toxlet.2005.07.001. PMid:16111842.
GÁBELOVÁ, A., VALOVICOVÁ, Z., HORVÁTHOVÁ, E., SLAMENOVÁ, D., BINKOVÁ, B., SRÁM, RJ. and FARMER, PB., 2004. Genotoxicity of environmental air pollution in three European cities: Prague, Kosice and Sofia. Mutation Research, vol. 563, no. 1, p. 49-59. http://dx.doi.org/10.1016/j. mrgentox.2004.05.014. PMid:15324748.

GOULART, M. and CALLISTO, M., 2003. Bioindicadores de qualidade de água como ferramenta em estudos de impacto ambiental. Revista FAPAM, vol. 2, no. 1, p. 78-85. Available from: $<$ http://www. apostilas.cena.usp.br/Valdemar/bioindicadores\%20 19.10.2010.pdf>. Access in: 16 dez. 2011.

GRISOLIA, CK., OLIVEIRA, ABB. and BONFIM, H., 2005. Genotoxicity evaluation of domestic sewage in a municipal wastewater treatment plant. Genetics and Molecular Biology, vol. 28 , no. 2, p. 334-338. http://dx.doi.org/10.1590/S141547572005000200026

GRISOLIA, CK. and STARLING, FLRM., 2001. Micronuclei monitoring of fishes from Lake Paranoá, under influence of sewage treatment plant discharges. Mutation Research, vol. 491, no. $1-2$, p. 39-44.

JHA, AN., 2008. Ecotoxicological applications and significance of the comet assay. Mutagenesis, vol. 23, no. 3, p. 207-221. http:// dx.doi.org/10.1093/mutage/gen014. PMid:18381356.

MAFFEI, F., CARBONE, F., FORTI, GC., BUSCHINI, A., POLI, P., ROSSI, C., MARABINI, L., RADICE, S., CHIESARA, E. and HRELIA, P., 2009. Drinking water quality: an in vitro approach for the assessment of cytotoxic and genotoxic load in water sampled along distribution system. Environment International, vol. 35, no. 7, p. 1053-1061. http://dx.doi.org/10.1016/j.envint.2009.05.007. PMid:19573924.

MARABINI, L., FRIGERIO, S., CHIESARA, E., MAFFEI, F., CANTELLI FORTI, G., HRELIA, P., BUSCHINI, A., MARTINO, A., POLI, P., ROSSI, C. and RADICE, S., 2007. In vitro cytotoxicity and genotoxicity of chlorinated drinking waters sampled along the distribution system of two municipal networks. Mutation Research, vol. 634, no. 1-2, p. 1-13. http://dx.doi.org/10.1016/j. mrgentox.2007.05.017. PMid:17884717.

MATSUMOTO, ST., MANTOVANI, MS., MALAGUTTII, MIA., DIAS, AU., FONSECA, IC. and MARIN-MORALES, MA., 2006. Genotoxicity and mutagenicity of water contaminated with tannery effluents, as evaluated by the micronucleus test and comet assay using the fish Oreochromis niloticus and chromosome aberrations in onion root-tips. Genetics and Molecular Biology, vol. 29, no. 1, p. 148-158. http://dx.doi.org/10.1590/S1415-47572006000100028.

MITCHELMORE, CL. and CHIPMAN, JK., 1998. DNA strand breakage in aquatic organisms and the potential value of the comet assay in environmental monitoring. Mutation Research, vol. 399, no. 2, p. 135-147. http://dx.doi.org/10.1016/S00275107(97)00252-2. PMid:9672656.

MORALES, MM., 2008. Métodos alternativos a utilização de animais em pesquisa científica: mito ou realidade? Revista Ciência e Cultura, vol. 60, no. 2, p. 33-36.

MOSMANN, T., 1983. Rapid colorimetric assay for cellular growth and survival: application to proliferation and cytotoxicity assays. Journal of Immunological Methods, vol. 65, no. 1-2, p. 55-63. http://dx.doi.org/10.1016/0022-1759(83)90303-4. PMid:6606682.

NADIN, SB., VARGAS-ROIG, LM. and CIOCCA, DR., 2001. A silver staining method for single-cell gel assay. The Journal of Histochemistry and Cytochemistry: Official Journal of the 
Histochemistry Society, vol. 49, no. 9, p. 1183-1186. http://dx.doi. org/10.1177/002215540104900912. PMid:11511687.

NUNES, EA., LEMOS, CT., GAVRONSKI, L., MOREIRA, TN., OLIVEIRA, NCD. and SILVA, J., 2011. Genotoxic assessment on river water using different biological systems. Chemosphere, vol. 84, no. 1, p. 47-53. http://dx.doi.org/10.1016/j. chemosphere.2011.02.085. PMid:21435689.

OHE, T., WATANABE, T. and WAKABAYASHI, K., 2004. Mutagens in surface waters: a review. Mutation Research, vol. 567, no. 2-3, p. 109-149. http://dx.doi.org/10.1016/j.mrrev.2004.08.003. PMid: 15572284.

PALUS, J., DZIUBAŁTOWSKA, E. and RYDZYŃSKI, K., 1999. DNA damage detected by the comet assay in the white blood cells of workers in a wooden furniture plant. Mutation Research, vol. 444, no. 1, p. 61-74. http://dx.doi.org/10.1016/ S1383-5718(99)00089-3. PMid:10477340.

PITARQUE, M., CREUS, A., MARCOS, R., HUGHES, JA. and ANDERSON, D., 1999. Examination of various biomarkers measuring genotoxic endpoints from Barcelona airport personnel. Mutation Research, vol. 440, no. 2, p. 195-204. http://dx.doi. org/10.1016/S1383-5718(99)00026-1. PMid:10209343.

Rio Grande do Sul. Fundação Estadual de Proteção Ambiental FEPAM, 2009. Qualidade das águas da bacia hidrográfica do Rio dos Sinos. FEPAM. Available from: <http://www.fepam.rs.gov. br/qualidade/qualidade_sinos/sinos.asp > . Access in: 27 Jul. 2012.

ROCHA, PS., AZAB, E., SCHMIDT, B., STORCH, V., HOLLERT, H. and BRAUNBECK, T., 2010. Changes in toxicity and dioxinlike activity of sediments from the Tietê River (São Paulo, Brazil). Ecotoxicology and Environmental Safety, vol. 73, no. 4, p. 550-558. http://dx.doi.org/10.1016/j.ecoenv.2009.12.017. PMid:20074803.

ROGERO, SO., LUGÃO, AB., IKEDA, TI. and CRUZ, AS., 2003. Teste in vitro de citotoxicidade: estudo comparativo entre duas metodologias. Materials Research, vol. 6, no. 3, p. 317-320. http://dx.doi.org/10.1590/S1516-14392003000300003.

São Paulo. Companhia Ambiental do Estado de São Paulo CETESB, 1988. Guia de coleta e preservação de amostras de água. São Paulo: CETESB. 150 p.
SCALON, MCS., RECHENMACHER, C., SIEBEL, AM., KAYSER, ML., RODRIGUES, MT., MALUF, SW., RODRIGUES, MAS. and SILVA, LB., 2010. Evaluation of Sinos River water genotoxicity using the comet assay in fish. Brazilian Journal of Biology = Revista Brasileira de Biologia, vol. 70, no. 4, supplement, p. 1217-1222. http://dx.doi.org/10.1590/S151969842010000600011. PMid:21225163.

SPILKI, FR. and TUNDISI, JG., 2010. Priority targets for environmental research in the Sinos River basin. Brazilian Journal of Biology $=$ Revista Brasileira de Biologia, vol. 70, no. 4, supplement, p. 1245-1247. http://dx.doi.org/10.1590/S151969842010000600014. PMid:21225166.

TICE, RR., AGURELL, E., ANDERSON, D., BURLINSON, B., HARTMANN, A., KOBAYASHI, H., MIYAMAE, Y., ROJAS, E., RYU, JC. and SASAKI, YF., 2000. Single cell gel/comet assay: guidelines for in vitro and in vivo genetic toxicology testing. Environmental and Molecular Mutagenesis, vol. 35, no. 3, p. 206-221. http://dx.doi.org/10.1002/(SICI)10982280(2000)35:3<206::AID-EM8>3.0.CO;2-J. PMid:10737956.

UDROIU, I., 2006. The micronucleus test in piscine erythrocytes. Aquatic Toxicology (Amsterdam, Netherlands), vol. 79, no. 2, p. 201-204. http://dx.doi.org/10.1016/j.aquatox.2006.06.013. PMid:16846653.

VARGAS, VMF., MIGLIAVACCA, SB., MELO, AC., HORN, RC., GUIDOBONO, RR., SÁ FERREIRA, IC. and PESTANA, MHD., 2001. Genotoxicity assessment in aquatic environments under the influence of heavy metals and organic contaminants. Mutation Research, vol. 490, no. 2, p. 141-158. http://dx.doi. org/10.1016/S1383-5718(00)00159-5. PMid:11342240.

ŽEGURA, B., HEATH, E., CERNOSA, A. and FILIPIC, M., 2009. Combination of in vitro bioassays for the determination of cytotoxic and genotoxic potential of wastewater, surface water and drinking water samples. Chemosphere, vol. 75, no. 11, p. 1453-1460. http://dx.doi.org/10.1016/j.chemosphere.2009.02.041. PMid:19307011. 